\title{
NANOFORMS OF Al (Fe, Mn)-DEPOSITING MICROORGANISM FROM A WIDE VARIETY OF HABITATS
}

\section{R.S. KUTUZOVA, N.I. VOROBYOV}

All-Russian Research Institute for Agricultural Microbiology, Federal Agency of Scientific Organizations, 3, sh. Podbel'skogo, St. Petersburg, 196608 Russia, e-mail kutuzova_rs@mail.ru

Acknowledgements:

Authors are thankful to the All-Russia Research Institute for Agricultural Microbiology employees E.E. Andronov and A.E. Pinaev for molecular genetic studies of the enrichment cultures provided.

Received October 15, 2014

\section{Abstract}

Due to advanced molecular methods of taxonomical attribution and quantification more data are recently accumulated about the activity of small forms in microbial communities. A substantial part of the bacteria from soil Fe-Mn concretions is known to exist as nanoforms which mostly are viable. Both among nanoforms and large bacteria there are the same phylogenetic groups. Nevertheless, most nanoforms still remain unidentified. Because of the role of $\mathrm{Al}(\mathrm{Fe}, \mathrm{Mn})$-depositing microorganism we earlier described in clay genesis it is widely spread in mineral fraction of the slag loose layer. The potential of this microorganism for Al detoxication by means of ion deposition on its surface is not estimated, and the meaning of $\mathrm{Al}(\mathrm{Fe}, \mathrm{Mn})$-depositing microorganism in soils with high $\mathrm{Al}$ acidity and toxicity is to be assessed. According to our data, many features of the $\mathrm{Al}(\mathrm{Fe}$, $\mathrm{Mn}$ )-depositing microorganism are the same as in saprophytic free-living mycoplasma-like microorganisms associated with primary bauxite formation. Herein we summarize our data on $\mathrm{Al}(\mathrm{Fe}, \mathrm{Mn})$ depositing microorganism from sod-podzolic soil and volcanic substrates of resent eruptions as initial stage of bauxite formation. So far as Al-depositing microorganism earlier found by T.B. Aristovskaya was described as related to Metallogenium from silt and widespread in soils, our investigations of Metallogenium bacteria also are under considerations. During cultivation of $\mathrm{Al}(\mathrm{Fe}, \mathrm{Mn})$-depositing microorganism the cells became smaller, so the scanning microscopy showed the ultra small forms sized $0.1-0.2 \mu \mathrm{m}$. In the fine fractions of volcanic substrate the thready structures were found consisting of the oval bodies of 0.1-0.3 $\mu \mathrm{m}$ diameter. The nanoforms were observed using electronic microscopy of silt Metallogenium preparation, in which the finest filaments of the colonies and surrounded bodies were much smaller than $0.2 \mu \mathrm{m}$. An attempt to assign the taxonomic status of the $\mathrm{Al}(\mathrm{Fe}, \mathrm{Mn})$-depositing microorganism using elective media and PCR-analysis failed because of inadequate DNA purification from $\mathrm{Al}$ and $\mathrm{Fe}$ contained in media and on the cell surface. Nevertheless, under strict conditions of cultivation the Methylobacterium widely spread in sodposzolic soils was revealed in all cultures.

Keywords: nanoforms, mycoplasma-like microorganism, $\mathrm{Al}(\mathrm{Fe}, \mathrm{Mn})$ microbial deposition, sod-podzolic soil, volcanic material, lake silt, Metallogenim, Methylobacterium.

The development of molecular biological methods and enhanced electron microscopic observations have changed the ideas about the quantitative and qualitative microbial diversity of soils and other natural habitats, contributing to greater attention to small forms with often unclear taxonomical position. Due to methodological difficulties, determination of their numbers and the role in ongoing processes is complicated [1-6]. A substantial part of bacteria (40\%) from soil $\mathrm{Fe}-\mathrm{Mn}$ concretions has been shown to exist as nanoforms which mostly (88$99 \%)$ are viable. Both among nanoforms and large bacteria there are the same phylogenetic groups. Nevertheless, most nanoforms still remain unidentified [7]. At the end of the last century, small forms were found in electron microscopic studies in Gallionella, Metallogenium and Siderococcus involved in the transformation of iron and manganese [8-11]. At that time, we confirmed the presence of similar size formations in Metallogenium and Siderococcus from fouling 
obtained in the secondary diagenetic profile of lake silt $[12,13]$; other unique tiny microorganisms [14] similar to those of soils [15] were identified as well.

In the 1970s, a microorganism precipitating aluminum on its surface was described in sod-podzolic soils and modern lateritic bauxites. It was pre-assigned to the group of Metallogenium-Siderococcus, ferromanganese microorganisms [16] belonging to active freshwater lake silt ore forming organisms [17]. To date, we have not only confirmed the existence of sod-podzolic soil Al-depositing organism in the form of $\mathrm{Al}(\mathrm{Fe}, \mathrm{Mn})$-depositing organism, but also revealed the presence of the similar organism in modern volcanic eruption material at the Kamchatka peninsula [18-20]. Involvement of $\mathrm{Al}$ (Fe, Mn)-depositing microorganism in the formation of high-alumina substance is due to the presence of the above substance in the mineral fraction of the surface-layer loose slag substrate covering a huge area and massively inhabited by this organism [21-24].

Our findings show that many features of $\mathrm{Al}$ ( $\mathrm{Fe}, \mathrm{Mn}$ )-depositing organisms may be considered from the standpoint of saprophytic free-living mycoplasma-like microorganisms involved in primary bauxite formation [24]. However, its importance for the soils of high acidity and aluminum toxicity is to be evaluated.

Aluminum belongs to basic soil typomorphic elements. Released from minerals, it migrates with the soil solution in the soil profile as a part of organoaluminum complexes, the transfer of which is a prerequisite of podzol formation. In case microflora uses the organic component of these compounds, it appears in the ionic form of $\mathrm{Al}^{3+}$. High concentrations of $\mathrm{Al}^{3+}$ cause aluminum toxicity of acid podzolic soils. Great attention is paid to the study of physiological, biochemical and genetic aspects of plant tolerance to $\mathrm{Al}^{3+}$ [25-29]. However, its excessive concentration may affect the activity of soil microorganisms adversely, especially of those applied to the soil as a bacterial preparation [3034]. The possible role of the microorganism under consideration in the removal of aluminum ions from the solution by depositing it on own structures has not been evaluated yet.

Our purpose was to demonstrate ultramicroscopic forms in $\mathrm{Al}(\mathrm{Fe}, \mathrm{Mn})$ depositing microorganisms, which is essential for the complete understanding of the participants involved in the soil processes.

Technique. Volcanic material was a sample with $\mathrm{pH}=1$ containing lesukite, a newly formed fine dispersed mineral phase containing impurity of pyroclastic particles $\left(13-40 \% \mathrm{Al}_{2} \mathrm{O}_{3}\right)$ [18, 19]. Soil samples were collected in longterm field experiments on sod-podzolic soil liming (Leningrad Institute of Agriculture, Belogorka settlement), and in stationary experiments (K.A. Timiryazev Moscow Agricultural Academy) at sod medium and weakly podzolic soils [20, 24].

To identify $\mathrm{Al}(\mathrm{Fe}, \mathrm{Mn})$-depositing microorganisms, we used preparations of the dust fraction of volcanic material and of enrichment cultures obtained by soil and volcanic material inoculation of Aristovskaya medium with low content of salts and aluminum lactate $(0.1 \mathrm{~g} / \mathrm{l})$ preferred by MetallogeniumSiderococcus microorganisms [16]. Apparently, the latter seems to be logical as some mycoplasmas are not capable of fermenting sugar or hydrolyze arginine, but oxidize lactate and pyruvate [35]. Sometimes, horse serum $(1 \mathrm{~g} / \mathrm{l})$ was used for culture activation. The acidity of $\mathrm{pH} 3.5-4.0$ was maintained which prevented aluminum chemical deposition on the microorganism cells [36]. For suppression of extraneous bacteria, ampicillin $(100 \mathrm{mg} / \mathrm{l})$ was added, in some cases in combination with thallium acetate $(30 \mathrm{mg} / 100 \mathrm{ml})$ [37]. To identify the Fe-depositing capability of microorganisms, Silverman and Lundgren $9 \mathrm{~K}$ medium was used for Acidithiobacillus ferrooxidans with ferrous sulfate in the form of Mohr's salt $(63 \mathrm{~g} / \mathrm{l})$ at initial $\mathrm{pH}=3.5$ which was reduced in the culture down 
to $\mathrm{pH}=1.0$. This medium is widely used for the studying species composition of acidophilus chemolithotrophic microorganism associations [38]. Our interest was determined by the identification of a microorganism similar to Metallogenium in the F. Walsh and R. Mitchell study [39, 40].

Aluminum deposit on microorganism surface was detected by $\mathrm{Al}^{3+}$ qualitative test (treatment of preparation with $0.1 \%$ aluminon solution in the presence of $3 \%$ acetic acid results in bright red lacquer color), and iron $\mathrm{Fe}^{3+}$ deposit was detected under the $1 \%$ sodium ferrocyanide exposure at mild $\mathrm{HCl}$ acidification or under $1 \%$ potassium rhodanide exposure at weak acidification as blue or blood red staining, respectively [41].

To study $\mathrm{Al}(\mathrm{Fe}, \mathrm{Mn})$-depositing microorganisms from sod-podzolic soils and modern erupted volcanic material, enrichment cultures were used, and $\mathrm{mi}-$ croorganisms were studied by light microscopy $(\times 100$, an Axiostar PLUS microscope, Carl Zeiss, Germany) in transmitted light and phase contrast. The results were documented using a camera. The method has been described in detail earlier [20].

For electron microscopy of Metallogenium, we used 1-1.5-month old lacustrine silt fouling on B.V. Perfiliev slot peloscopes obtained in the secondary diagenetic profile. After the removal and examination using light microscope, a fine stream of carbon was deposited onto specimens using a carbon rod to form thin film in the area of young colonies. A thin layer of gelatin was applied over the coating, dried, cut, and placed on the surface of warm water with the gelatin layer down to remove it. "Replicas with extraction» were examined using an electron microscope Tesla BS-242 (Czechoslovakia) [12-14].

Results. As noted, the most spectacular and characteristic morphological form of Al-precipitating microorganisms was a large colony (diameter of $120-150 \mu \mathrm{m}$ ) with radial threads of oval bodies extending from its center (Fig. 1, a). They are similar to trichospherical Metallogenium colonies of lake silt named by their discoverers [17]. We observed a plurality of radial branching filaments formed of oval bodies with the size of about $1 \mu \mathrm{m}$, and the tiered arrangement of structures around the center. However, free bodies with the diameter of 1-4 $\mu \mathrm{m}$ with a thick central portion and a transparent mucous capsule-like aureole were the dominant forms (see Fig. 1, b).

Along with small objects, 1.5-3-month old enrichment culture contained large oval forms $(5-10 \mu \mathrm{m})$ where the supposed capsule did not seem a mucous formation. It appears clearly structured as radial threads with a rough surface (see Fig. 1, c). After removing $\mathrm{Al}$ deposits from the objects, a dense center with thin threads consisting of ultra small particles growing around it (less than $1 \mu \mathrm{m}$, see Fig. 1, d) showed up.

In old cultures (12 months or older), there were many mildly mineralized colonies acquiring pink and pale pink explained only by low aluminum content in the culture medium due to deposition on the surface of predecessors (see Fig. 1, e). Here, there were also growths free from aluminum deposits detected by conventional biological staining [24]. They were single or formed felt type clusters of cocci-filamentous forms with the size of their constituent bodies to 1 $\mu \mathrm{m}$ (Fig. 2, a). Scanning electron microscopy (JSM-6390 LA, JEOL, Japan) revealed the presence of a large number of very small forms $(0.1-0.2 \mu \mathrm{m})$, that is nanoforms, in mature enrichment cultures (see Fig. 2, b). Adaptation to unfavorable growth conditions, primarily to substrate limitation, results in the transformation of vegetative cells into mini-bodies [1-7].

In electron microscopic studies (Hitachi H-300, Japan) of the fine fraction of volcanic material, actually lesukite, we had to deal with extremely small 
objects constantly $[18,19]$. The suspension of water turbid material was treated with $10 \%$ hydrochloric acid to reliably remove aluminum and iron from organism structures.

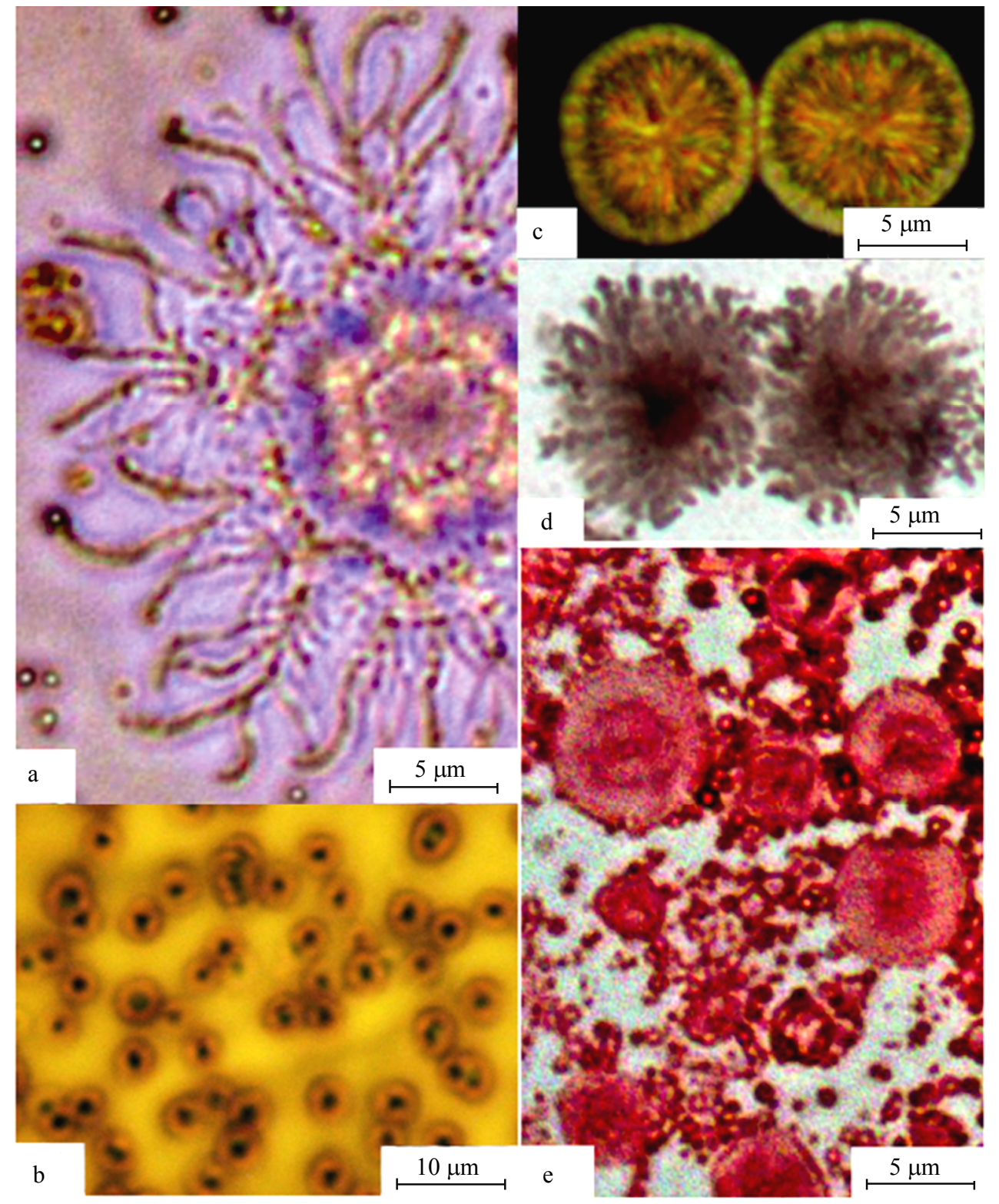

Fig. 1. Enrichment culture of Al-depositing microorganism after long cultivation: a - trichospherical colonies with apparent radial threads of oval bodies (early period of cultivation); b - small oval bodies with a dense center are surrounded by a capsule-like structure; c, d - large oval bodies with radial structure (before and after treatment with tannin containing reagent); e - pink «balloon»-like colonies and predominating small colonies to the end of cultivation (light microscopy, an Axiostar PLUS microscope, Carl Zeiss, Germany).

After sedimentation, the surface fraction of liquid phase was used. Thread structures (apparently radial outgrowths of trichospherical colonies) did not look mineralized (see Fig. 2, c, d, e). At a significant magnification, the microorganisms released of deposits had the appearance of a chain of oval, irregularly spherical, pear-shaped bodies, the nanoforms [1], sized from 0.1 to $0.3 \mu \mathrm{m}$. They form a thread of bodies with a dense center and less dense environment [2]. There was 


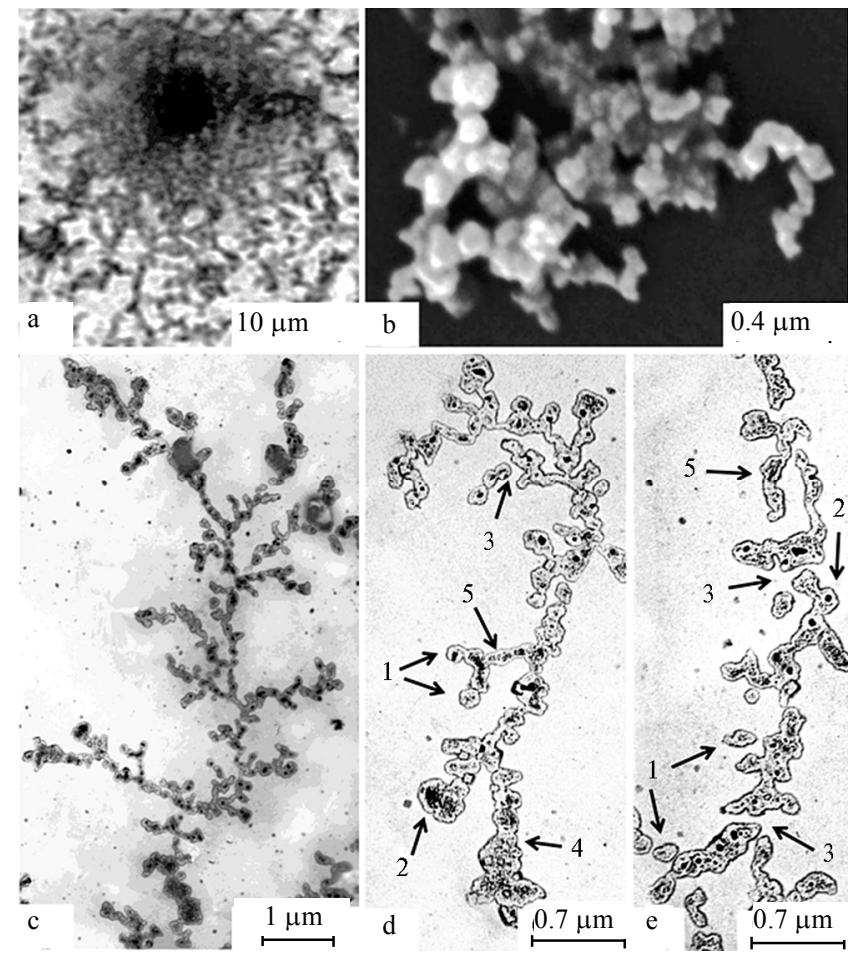

Fig. 2. Nanoforms of the organism studied: a - small bodies detected using biological staining after 1 year of cultivation (light microscopy, an Axiostar PLUS, Carl Zeiss, Germany,) b - small bodies in enrichment culture (scanning electron microscopy, an JSM-6390 LA, JEOL, Japan), c - general view of the fine lesukite fraction thready structures, d, e - separate areas of this growth thread containing bodies of oval or irregular form (1), bodies with a dense center and bright surrounding (2), loosely binded bodies (3), bodies in the form of lump (4), bodies in the form of chain (5) (transmission electron microscopy, a Hitachi H300, Japan). no strong binding between the areas of threadlike structures (it was loose) [3]. Some areas formed lumps (4) or were presented as if by threads of unseparated forms (5) (see Fig. 2, b, c). This characteristic is largely consistent with that for mycoplasma reproducing by irregular division (that is why bodies of different shape and size are found in the culture) $[34,36]$.

The great similarity of the identified $\mathrm{Al}$ (Fe, Mn)-depositing microorganism to Metallogenium [18-20, 24] and its wide dissemination in the soil made it possible to use the published (Fig. 3 , a, b) [12] and unpublished (see Fig. 3, c, d) pictures of «replicas with extraction». Threads with uneven surface indicating the presence of small oval bodies under dark manganese deposits were seen inside the mineralized radial growths of the Metallogenium colony. The end of one of the radial colony «sprout» becomes a thin thread with ultra small oval bodies on it (see Fig. 3, a). The size of such a thread and bodies exclude the presence of cellular structure. In another young and weakly mineralized colony, threads growing from the center had a clear roughness formed by ultra small bodies that were beginning to develop (see Fig. 3, b). There was also a chain of bodies, the nanoforms, with a dense center and a less dense aureole, similar to the one identified in an $\mathrm{Al}(\mathrm{Fe}$, $\mathrm{Mn}$ )-depositing organism from volcanic material and sod-podzolic soils (see Fig. 3 , c). Findings of «felt»-like balls formed of a mineralized oval body and intertwining thready clusters of high and low mineralization, are of interest (see. Fig. 3, d). Here, among filamentous growths and oval forms, there were a great number of ultra small structures radiating from the center like in a colony. They were also observed in other images in this series. These small objects (sized significantly less than $0.2 \mu \mathrm{m}$ ) attracted our attention due to the «replicas with extraction» so far as in the absence of the entire image of the whole structure they could go unnoticed. At present, again, the researchers point out the need to study undamaged microbiocenose architecture but at the ultramicroscopic level [42, 43].

It is believed that at the size of bodies to $0.20 \mu \mathrm{m}$, they can not fit the minimum set of mandatory cell elements ensuring its functioning. However, fil- 
ters with a pore diameter of $0.22 \mathrm{rm}$ used for purification of samples of water, sera, and various medical solutions do not preclude bacteria nanoforms including

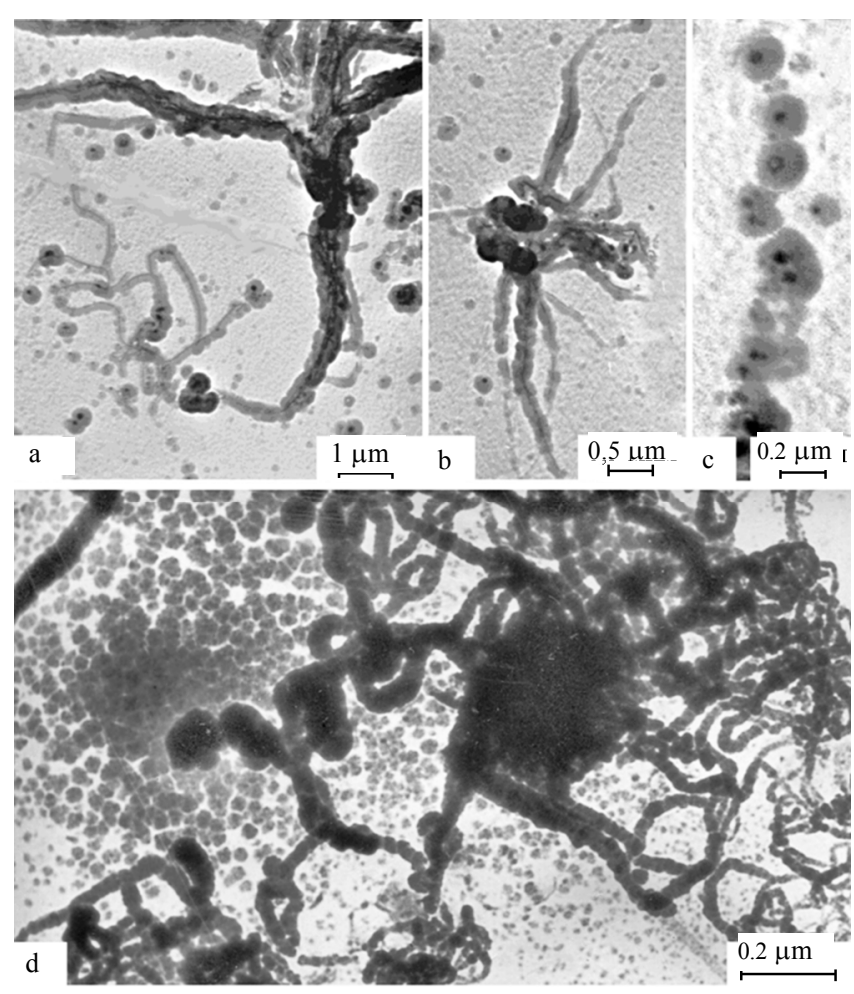

Fig. 3. Electron microscopy of Metallogenium of young fouling on slit peloscopes: a - colony area with one of the «sprout» becoming a thin thread with small oval bodies on it; b - young colony with rounded cells in the center and bodies forming its threads; c - chain of oval bodies with a dense center and capsule-like surrounding; $d-$ oval and threadlike growths and ultramicroscopic forms located around (a Tesla BS-242 microscope, Czechoslovakia). mycoplasma not only causing plant diseases but also posing a threat to human and animal health. Vesicles with the size range of 20-200 $\mathrm{nm}$ are referred to the smallest bacterial formations. Extracellular membrane vesicles of bacteria, mycoplasma, and $\mathrm{mi}^{-}$ croscopic algae provide transportation of a vast variety of compounds involved in intercellular communication and adaptation to environmental conditions [44-48].

The Al (Fe, Mn)depositing organism found in soil and volcanic material is similar to Metallogenium of lake silt in its cultural and morphological featured and has properties similar to those of saprophytic mycoplasmas. To date, it belongs to taxons not studied by molecular genetic methods. We provided three enrichment cultures for the analysis. Two media (Aristovskaya medium with a full set of components, including blood serum, ampicillin, and thallium acetate, and Silverman and Lundgren $9 \mathrm{~K}$ medium for $A$. ferrooxidans) were inoculated with volcanic material; as a result, two enrichment cultures (with an Al-depositing and a Fe-depositing microorganisms) were obtained. The third culture was prepared by reinoculation of an Al-depositing microorganism grown in Aristovskaya medium into fresh Silverman and Lundgren medium, however, $\mathrm{pH}$ of the latter did not change as $A$. ferrooxidans development in Aristovskaya medium was suppressed by ampicillin and thallium acetate, and it was absent in the material used for reinoculation.

An attempt was made to study bacterial diversity in the three presented enrichment cultures using real time PCR technology. The peculiarity of these samples consists in the fact that the enrichment cultures were obtained as a result of elective conditions for the development of a narrow range of specific microorganisms. Besides, insufficient purification of DNA preparation from aluminum and iron contained in the medium and on the cell surface of microorganisms could play its role. Al-depositing and $\mathrm{Fe}$-depositing organisms were not identified. Methylobacterium was dominant in all three cultures characterized by very low diversity. On Silverman and Lundgren $9 \mathrm{~K}$ medium, under the $\mathrm{pH}$ decrease from 3.5 to 1.0, it was identified as Methylobacterium fujsawaense at a $98 \%$ significance 
level. In two other cases, the order Rhizobiales was presented by the only family Methylobacteriaseae with a single representative of Methylobacterium.
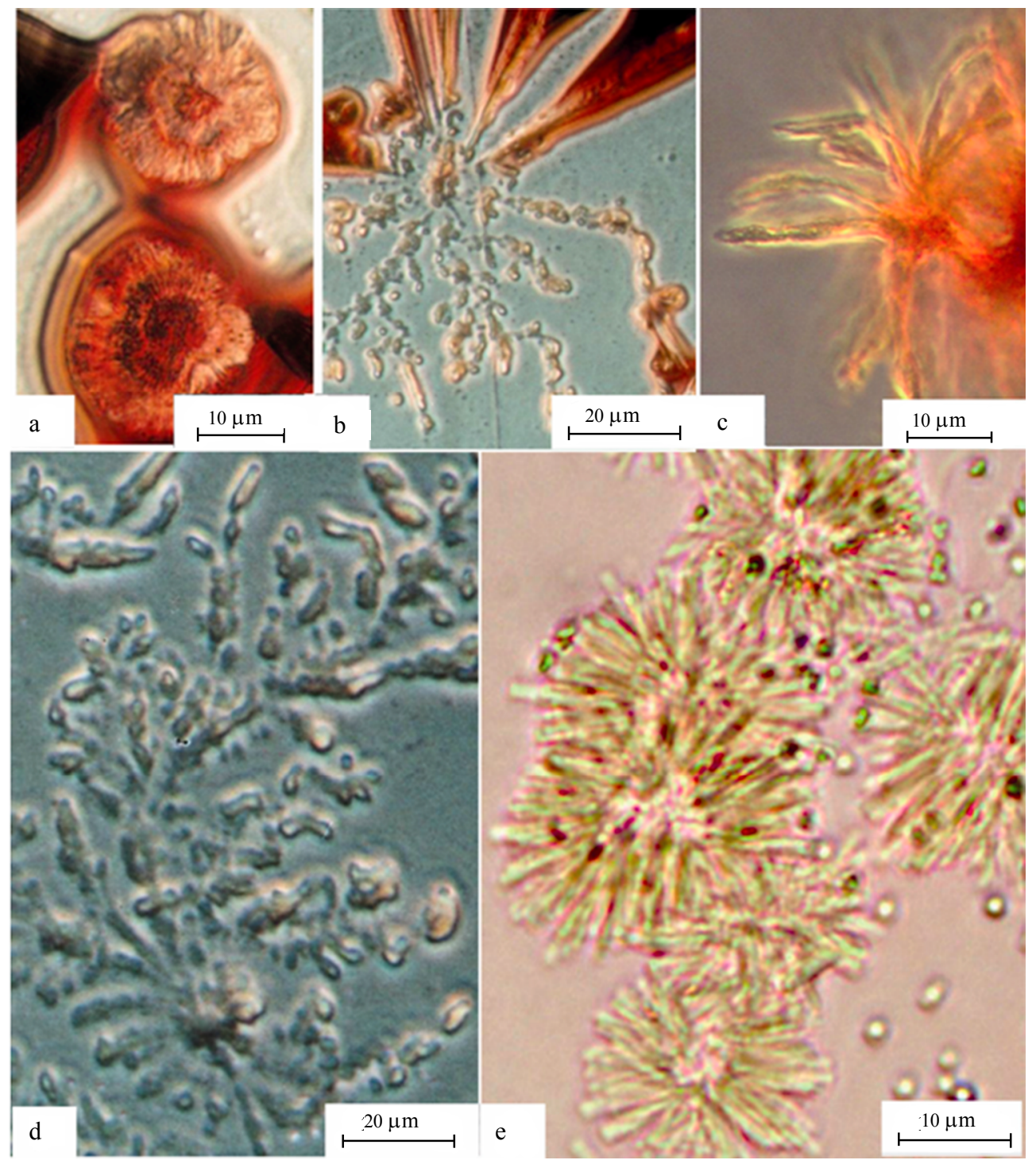

Fig. 4. Residual mineralization of Fe-depositing microorganism on Silverman and Lundgren $9 \mathrm{~K}$ medium at initial $\mathrm{pH}$ decreased to $1,0(\mathrm{a}, \mathrm{b}, \mathrm{d})$ and remained unchanged at $3,5(\mathrm{c}, \mathrm{e})$, visualized by treatment with $\mathrm{K}$ rhodanide: $\mathrm{a}, \mathrm{b}, \mathrm{c}-\mathrm{a}$ residual blood red Fe-compounds are detained; $\mathrm{d}$, e - no blood red Fe-compound observed but an inner structure of the radial threads is not apparent $(\mathrm{d}-\mathrm{a}$ radial threads are rigid in structure and yellowish and light rusty in color, e - «hedgehog»-like colonies) (light microscopy, an Axiostar PLUS microscope, Carl Zeiss, Germany).

Methylobacterium is an optional methanotroph and more methylotroph capable of using $\mathrm{C}_{1}$ organic compounds. Its presence in all three obtained enrichment cultures indicates its presence in modern volcanic eruption material and characterizes this organism as an acid resistant and aluminum tolerant one. Wide dissemination of methylotrophic bacteria in sod-podzolic soils with aluminum acidity and aluminum toxicity is known [49]. Mutually beneficial relations of Methylobacterium with plants is determined, as it is not only considered as an epiphyte using methanol, a product of their metabolism, but also stimulates plant growth and development due to the production of bioactive substances such as phytohormones and vitamins $[50,51]$. 
The example of microorganism functioning as Fe-depositing ones on Silverman and Lundgren $9 \mathrm{~K}$ medium has particularly well illustrated how great mineral deposition on the surface of microbial cells can be (in one case at final $\mathrm{pH}=1.0$, in another case at $\mathrm{pH}=3.5$ ). The use of potassium rhodanide which forms a blood-red water soluble iron compound freed objects from deposits just partially (Fig. 4, a, b, d). Residual iron persisted in more complex forms that did not react with potassium rhodanide [10]. As a result, specific bodies with a dense center and capsule-like surrounding (see Fig. 4, c) remained hidden under distinct radial tuberosity of radial threads, or colony radial threads maintained a rigid structure in the form of yellowish or light rust needles and the very colonies took the form of a hedgehog (see Fig. 4, d).

In general, it should be mentioned that currently studies focus on iron bacteria [6, 7], but the existence of the Fe-Mn Metallogenium-Siderococcus bacteria group has not bee confirmed by modern molecular genetic methods yet, although they are widely disseminated in the soil [16] and are dominant in freshwater lake silts [17]. Accordingly, modern methods to estimate their number and the number of $\mathrm{Al}(\mathrm{Fe}, \mathrm{Mn})$-depositing microorganisms can not be offered. Since labile aluminum inhibits the development of the plant root system and enhances the effects of other stressors, coordination of biological detoxification of this aluminum form could be significant. This would be facilitated by a comparison of the number of $\mathrm{Al}(\mathrm{Fe}, \mathrm{Mn})$-depositing microorganisms with agrochemical indices based on multiple correlation analysis, i.e. the use of graph analysis method which has been positively proven in previous studies [52, 53]. Some attempts to develop the methods of precipitation and detoxification of labile aluminum as a way to increase the productivity of acidic podzolic soils have already been taken by researchers [54].

Thus, we demonstrated electron microscopic forms (nanoforms of the size range of $0.2 \mu \mathrm{m})$ in an $\mathrm{Al}(\mathrm{F}, \mathrm{Mn})$-depositing microorganism identified in volcanic material and sod-podzolic soils and considered closely related to Metallogenium of lake silts. «Replicas with extraction» of slit fouling revealed ultramicroscopic forms of Metallogenium (size much smaller than $0.2 \mu \mathrm{m}$ ). An attempt to assign the taxonomic status of the $\mathrm{Al}(\mathrm{Fe}, \mathrm{Mn})$-depositing microorganism using elective media and PCR-analysis failed because of inadequate DNA purification from $\mathrm{Al}$ and $\mathrm{Fe}$ contained in media and on the cell surface. Nevertheless, under strict conditions of cultivation, Methylobacterium widely spread in sod-poszolic soils was revealed in all cultures.

\section{REFERENCES}

1. Vainshte in M.B., Kudry a shova E.B. Mikrobiologiya, 2000, 69(2): 163-174.

2. Pa n k rat ov T.A., B e lova S.E., D e d y s h S.N. Mikrobiologiya, 2005, 74(6): 811-837.

3. $\mathrm{Ab}$ a s h i n a T.N. Izmenenie strukturnoi organizatsii bakterial'nykh kletok pri stressovykh vozdeistviyakh. Avtoreferat kanidatskoi dissertatsii [Changes in structural organization of stressed bacterial cells. PhD Thesis]. Moscow, 2007.

4. Chernov V.M., Mukhametshina N.E., Gogolev Yu.V., Nesterova T.N., Ch e rn ov a O.A. Doklady RAN, 2007, 413(3): 271-275.

5. Duda V.I., Suzina N.E., Polivtseva V.N., Boronin A.M. Mikrobiologiya, 2012, 81(4): 415-427.

6. V a n' k o v a A.A. Nanoformy bakterii v sisteme «pochva-rastenie». Avtoreferat dokorskoi dissertatsii [Nanoforms of bacteria in soil-plant system. DSci Thesis]. Moscow, 2013.

7. Lysak L.V., Kadulin M.S., Konova I.A., Lapygina E.V., Ivanov A.V., Zvy a g intse v D.G. Pochvovedenie, 2013, 6: 707-714.

8. Dubinina G.A. Untersuchungen uber die Morphologie von Metallogenium und die Beziehungen zu Mycoplasma. Zeitschrift fur Allg. Mikrobiologie, 1970, 10(5): 309-320.

9. D u b i n i n a G.A., D e ry u g i n a Z.P. Doklady AN SSSR, 1971, 201(3): 714-716.

10. B a la s hova V.V. Mikoplazmy i zhelezobakterii [Mycoplasms and iron bacteria]. Mos- 
cow, 1974.

11. B a la s hova V.V., D u b i n i n a G.A. Mikrobiologiya, 1989, 58(5): 841-846.

12. Kutuzova R.S., Gabe D.R., Kravki na I.M. Mikrobiologiya, 1972, 41(6): 1099-1102.

13. Kutu z ova R.S. Mikrobiologiya, 1974, 43(2): 285-288.

14. Ku t u z ov a R.S. Mikrobiologiya, 1972, 41(5): 859-861.

15. Nikit in D.I., Vasil'eva L.V., Lo kh macheva R.A. Novye $i$ redkie formy pochvennykh mikroorganizmov [New and rare forms of soil microorganisms]. Moscow, 1966.

16. Aristovskay a T.V. Mikrobiologiya protsessov pochvoobrazovaniya [Microbiology of soil formation]. Leningrad, 1980.

17. Pe rfil'e v B.V., G ab e D.R. V sbornike: Rol' mikroorganizmov v obrazovanii zhelezomargantsevykh ozernykh rud [In: The role of microorganisms in formation of Fe-Mn lake ore]. Moscow-Leningrad, 1964: 16-53.

18. Kutuzova R.S., Vergas ova L.P., F i lat ov S.K. Vulkanologiya i seismologiya, 2004, 1: $46-54$.

19. Kutu zova R.S., Vergas ov a L.P., Fil at ov S.K. Pochvovedenie, 2006, 3: 334-343.

20. Ku t u z ov a R.S. Sel'skokhozyaistvennaya biologiya [Agricultural Biology], 2011, 3: 102-107. (http://www.agrobiology.ru/3-2011 kutuzova-eng.html).

21. Filatov S.K., Vergasova L.P., Kutuzova R.S., S t e panova E.L. Polyakov a I.G. Zapiski Vserossiiskogo mineralogicheskogo obshchestva, 2004, CXXXIII(3): 1-11.

22. Kut u z ova R.S., Ve rg a s ova L.P., Fil a t o v S.K. Aluminium-precipitating microorganism in products of recent volcanic activity. Proc. Int. Workshop «Biodiversity, molecular biology and biogeochemistry of thermophiles». Petropavlovsk, Kamchatka Peninsula, 2010: 36-38.

23. Fil at ov S.K., Verg a s ov a L.P., Kutuz ov a R.S. Decomposition of alumosilicates and accumulation of aluminum by microorganisms on fumarole fields of Tolbachik volcano (Kamchatka Peninsula, Russia). In: Minerals as advanced materials-II. S.V. Krivovichev (ed.). Springer Verlag, 2011: 389-399.

24. Kutuzova R.S., Vorob'ev N.I. Alyuminii-osazhdayushchii mikroorganizm [An Alprecipitating microorganism]. Lambert Academic Publishing, Saarbrucken, 2013.

25. K li m as h evski i E.L. Geneticheskii aspekt mineral'nogo pitaniya rastenii [Genetic aspects of plant mineral nutrition]. Moscow, 1991.

26. Puk hal's k a y a N.V. Agrokhimiya, 2005, 8: 70-82

27. Li s its y n E.M. Potentsial'naya alyumoustoichivost' sel'skokhozyaistvennykh rastenii i ee realizatsiya $v$ usloviyakh evropeiskogo severo-vostoka Rossii. Avtoreferat dokorskoi dissertatsii [Potential aluminum tolerance of agricultural plants and its implementation in the European North-East of Russia. DSci Thesis]. Moscow, 2005.

28. Lis its y n E.M., Lis its y n a I.I. Sel'skokhozyaistvennaya biologiya [Agricultural Biology], 2008, 5: 58-64.

29. Tolpes ht a I.I., S o k olova T.A. Pochvovedenie, 2009, 1: 29-41.

30. Wo o d M. A mechanism of aluminium toxicity to soil bacteria and possible ecological implications. Plant and Soil, 1995, 171: 63-69 (doi: 10.1007/BF00009566).

31. I $11 \mathrm{me} \mathrm{r} \mathrm{P.,} \mathrm{S} \mathrm{chinner} \mathrm{F.} \mathrm{Influence} \mathrm{of} \mathrm{nutrient} \mathrm{solution} \mathrm{on} \mathrm{Al-tolerance} \mathrm{of} \mathrm{Pseudomonas}$ sp. FEMS Microbiol. Lett., 1999, 170: 135-190.

32. Shi rokikh A.A., Shi rokikh I.G. Agrokhimiya, 2004, 12: 41-46.

33. Shirokikh A.A., Shirokikh I.G., Polyanskaya L.M., Rodina N.A., Burkan o v a O.A. Agrokhimiya, 2004, 8: 36-42.

34. I $11 \mathrm{me} \mathrm{r}$ P., E r l e b a k h K. Mikrobiologiya, 2005, 74(6): 852-855.

35. Borkhsenius S.N., Chernova O.A., Chernov V.M., Vonski i M.S. Mikoplazmy [Mycoplams]. St. Petersburg, 2002.

36. S a fo nova O.F., Furmakova L.N., B ronevoi V.A, Tsekhovol'skaya D.Yu., K i m Yu.I., K o p e i k i n V.A. V sbornike: Problemy genezisa boksitov [In: Bauxite genesis]. Moscow, 1975: 280-288.

37. Mikoplazmy v patologii zhivotnykh /Pod redaktsiei G.F. Koromyslova, Ya. Mesarosha, L. Shtipkovicha et al. [Mycoplasms in animal pathology. G.F. Koromyslov, Ya. Mesarosh, L. Shtipkovich et al. (eds.)]. Moscow, 1987.

38. Karavaiko G.I., Kuznetsov S.I., Golomzik A.I. Rol' mikroorganizmov $v$ vyshchelachivanii metallov iz rud [The role of microorganisms in leaching metals from ores]. Moscow, 1972.

39. Wals h F., Mitchell R. A pH-Dependent succession of iron bacteria. Environ. Sci. Technol., 1972, 6(9): 809-812.

40. Walsh F., Mitchell R. An acid-tolerant iron-oxidizing Metallogenium. J. Gen. Microbiol., 1972, 72: 369-376 (doi: 10.1099/00221287-72-2-369).

41. Vasil'ev V.V., Grigor'ev N.N. Prakticheskoe rukovodstvo po kachestvennomu khimicheskomu polumikroanalizu [Practical guide to chemical quantitative semi-microanalysis]. Leningrad, 1966.

42. Kordyum V.A., Moshinets E.V., Tsapenko M.V., Adamchuk-Chalay a N.I., I rodov D.I., A nd rie n k o V.I., S h p i lev y a S.P. Biopolimeri i klitina, 2008, 
24(5): 412-425.

43. Kordyum V.A., Shpilevaya S.P., Moshinets E.V., Adamchuk-Chalay a N.I., I rod o v D.I., A n d ri e n k o V.I. Biopolimeri i klitina, 2009, 25(2): 150-166.

44. Volkov V.T., Volkova N.N., Smirnov G.V., Polienko A.N., Bakirov A.G., E rmola e v V.A. Biomineralizatsiya $v$ organizme cheloveka i zhivotnykh [Biomineralization in humans and animals]. Tomsk, 2004.

45. V a s i l'e v a N.V. Rol' vneshnemembrannykh vezikul v sekretsii bakterioliticheskikh fermentov Lysobacter sp. Avtoreferat kandidatskoi dissertatsii [The role of external membrane vesicles in Lysobacter sp. bacteriolytic enzyme secretion. PhD Thesis]. Moscow, 2010.

46. Ponomarev A.P. Elektronnaya mikroskopiya nanobakterii $i$ drugikh predstavitelei mikro- i nanomira [Electron microscopy of nanobacteria and other micro and nano forms]. Vladimir, 2011.

47. Chernov V.M., Chernova O.A., Gorshkov O.V., Baranova N.B., Muzykantov A.A., Nesterova T.N., Ponamoreva A.A. Doklady RAN, 2013, 450(4): 483-487.

48. Bille r S.J., Schubotz F., Roggensack S.E., Thompson A.W., S u m mons R.E., Chisholm S.W. Bacterial vesicles in marine ecosystems. Science, 2014, 343(6167): 183-186 (doi: 10.1126/science. 1243457).

49. S h i rokik h A.A., P le t n e va G.V. Doklady RASKHhN, 2000, 2: 30-33.

50. Shi rokikh A.A., Shi rokik h I.G. Agrokhimiya, 2007, 9: 53-57.

51. Fedorov D.N., Doronina N.V., Trotsenko Yu.A. Mikrobiologiya, 2011, 80(4): $435-446$.

52. Vorob'ev N.I., Sviridova O.V., Kutuzova R.S. Metodicheskie rekomendatsii po ispol'zovaniyu graf-analiza $v$ issledovaniyakh sistem, sostoyashchikh iz bioticheskikh $i$ abioticheskikh komponentov [Guidelines on the use of graph-analysis in the study of the systems which consist of biotic and abiotic components]. St. Petersburg, 2006.

53. Kutuzova R.S, Vorob'ev N.I, Popova L.A., Gamova M.V., Kruglov Yu.V. Pochvovedenie, 2009, 2: 244-254.

54. Ponomareva L.V., D richko V.F., Tsvetkova N.P., Kudryavtsev D.V. Sel'skokhozyaistvennaya biologiya [Agricultural Biology], 2010, 1: 104-109. 